\title{
JURISPRUDENCIA DE LA CORTE SUPREMA SOBRE LA DILIGENCIA DE ENTRADA Y REGISTRO EN LUGAR CERRADO. UNA DOCTRINA DE PUERTAS ABIERTAS
}

\author{
JURISPRUDENCE OF THE SUPREME COURT ABOUT THE \\ DILIGENCE OF ENTRY AND SEARCH IN A CLOSED PLACE. A \\ DOCTRINE OF OPEN DOORS
}

MANUEL RODRÍGUEZ VEGA***

\section{RESUMEN}

En el presente trabajo se examina la jurisprudencia de la Corte Suprema chilena de los años 2016 a 2020 concerniente a diversas problemáticas de la diligencia de entrada y registro de edificio o lugar cerrado, y su conformidad con los principios de proporcionalidad, interpretación restrictiva $\mathrm{y}$ especialidad que deben imperar tratándose de actuaciones que privan, restringen o perturban los derechos a la privacidad y a la inviolabilidad del hogar, estudio que demuestra que su interpretación del estatuto que regula este procedimiento, en general, tiende a ampliar el campo del actuar autónomo policial, sustrayéndolo de la dirección y control del fiscal y de los tribunales, con el consiguiente riesgo y detrimento para el respeto de dichos derechos.

Palabras clave: Jurisprudencia, Corte Suprema, Entrada y registro, Lugar cerrado, Inviolabilidad del hogar, Derecho procesal penal.

* Profesor Asistente Adjunto, Facultad de Derecho, Pontificia Universidad Católica de Chile, Santiago, Chile. Doctor en Derecho, Universidad de Chile. Magíster en Derecho Penal, Universidad de Talca. Licenciado en Ciencias Jurídicas y Sociales, Pontificia Universidad Católica de Chile. Correo electrónico: merodrig@uc.cl. ORCID: https://orcid.org/0000-0001-6439-5097.

** Agradezco a quienes oficiaron como árbitros anónimos en el proceso de revisión de este trabajo, por sus observaciones que hicieron posible subsanar errores de fondo y forma, y muy especialmente a la estudiante de Derecho, Amelia Muñoz Molina, por su muy valiosa colaboración en la redacción de la versión final de este texto.

Trabajo recibido el 31 de marzo de 2020, y aprobado para su publicación el 20 de mayo de 2021. 
This paper examines the jurisprudence of the Chilean Supreme Court from 2016 to 2020 concerning various issues of the diligence of entry and search of a building or closed place, and its compliance with the principles of proportionality, restrictive interpretation and specialty that should prevail when dealing with actions that deprive, restrict or disturb the rights to privacy and the inviolability of the home. This study shows that, in general, the interpretation of the statute that regulates this procedure tends to broaden the scope of discretion used by the police, removing it from the control of the prosecutor and the Courts, with the consequent risk and detriment for the respect of said rights.

Keywords: Jurisprudence, Supreme Court, Entry and search, Closed place, Inviolability of the home, Criminal procedure law.

\section{INTRODUCCIÓN}

La diligencia de entrada y registro en lugar cerrado, regulada en los artículos 205 a 216 del Código Procesal Penal -en adelante, CPP-, tiene como objetivo la búsqueda del imputado o de rastros o huellas del hecho investigado o medios que pudieren servir a la comprobación del mismo $\mathrm{y}$, normalmente, conlleva la afectación o perturbación de los derechos fundamentales a la privacidad e inviolabilidad del hogar, reconocidos en los $\mathrm{N}^{\circ}$ s. 4 y 5 del artículo 19 de la Constitución Política de la República, así como en los artículos 17 del Pacto Internacional de Derechos Civiles y Políticos y 11 de la Convención Americana de Derechos Humanos, por lo cual su turbación por los cuerpos de persecución se supedita a tres supuestos que pueden sintetizarse por ahora como el consentimiento del titular, la flagrancia del delito y la autorización judicial. ${ }^{1}$

\footnotetext{
${ }^{1}$ Analizaremos conjuntamente las actuaciones de entrada y de registro, aunque como bien aclara Ros, Emilia, La configuración jurídica de la orden de entrada y registro, Bubok, Madrid, 2017, p. 19, se trata de actos diferentes, el primero de los cuales no siempre implica el segundo, pues la entrada puede tener por objeto únicamente la detención de una persona y agotarse con ella, mientras que el registro supone la entrada. Para una condensada exposición de los requisitos de esta diligencia de acuerdo a nuestro ordenamiento, v. OLIVER, Guillermo, "Facultades autónomas de la policía en el sistema procesal penal
} 
Si bien el $\mathrm{N}^{\circ} 5$ del citado artículo 19, al establecer que el allanamiento sólo puede realizarse en los casos y formas determinados por la ley, alude exclusivamente al "hogar", ello no importa que carezcan de tutela otros lugares que no admitan esa categorización. ${ }^{2}$ En efecto, el inciso $3^{\circ}$ del artículo 83 de la Constitución y, concordantemente, el artículo 9 CPP, prescriben que toda actuación del procedimiento que privare, restringiere o perturbare el ejercicio de los derechos que la Constitución asegura, como el respeto y protección a la vida privada garantizado en el $\mathrm{N}^{\circ} 4$ del artículo 19, requerirá de autorización judicial previa, por lo que incluso en emplazamientos no calificables como el "hogar" de una persona -o incluso que no puedan tipificarse como "lugar cerrado"- si en ellos es posible reconocer un ámbito o esfera en que pueda albergarse una expectativa razonable de privacidad, ${ }^{3}$ su acceso y registro igualmente está condicionado a los tres supuestos arriba mencionados. En otras palabras, los valores de privacidad e intimidad constitucionalmente custodiados, definen y consecuencialmente amplifican, funcional o materialmente los lugares protegidos, pues, como acertadamente lo ha dicho la Corte Suprema de Estados Unidos, en relación a la cuarta enmienda, la Constitución "protects people, not places". 4

chileno", Revista de Derecho P. Universidad Católica de Valparaíso, 2018, v. 51, pp. 60 y 61, y NúÑEZ, Raúl; CORREA, Claudio, "La prueba ilícita en las diligencias limitativas de derechos fundamentales en el proceso penal chileno. Algunos problemas", Ius et Praxis, 2017, N 1, pp. 202-203.

${ }^{2}$ Igual conclusión en Horvitz, María I.; LóPEz, Julián, Derecho procesal penal chileno, Editorial Jurídica, Santiago, 2008, $1^{\text {a }}$ ed., T. I, p. 513 y CERDA, Rodrigo, Manual del sistema de justicia penal, Librotecnia, 2013, $2^{\text {a }}$ ed., T. I., p. 263.

${ }^{3}$ Concepto acuñado en Suprema Corte (Estados Unidos), Katz v. United States, 389 U.S. 347 (1967), https://www.oyez.org/cases/1967/35, consultada: 20 de abril de 2021, y que ha sido recogido por nuestro Máximo Tribunal en diversos pronunciamientos, entre muchos, Corte Suprema, 4 de enero de 2016, Rol No 89660-16; Corte Suprema, 27 de febrero de 2017, Rol No 3-17; Corte Suprema, 24 de julio de 2017, Rol N 24860-17; Corte Suprema, 29 de enero de 2019, Rol N 32691-18; y Corte Suprema, 8 de abril de 2021, Rol N 14317-21. Como sintetiza Escobar, Javier, "¿Se vulnera el derecho a la privacidad si la policía utiliza, para efectos de una investigación criminal, fotografías del imputado obtenidas desde Facebook? Comentario a la sentencia rol No 3-2017 de la Corte Suprema", Estudios Constitucionales, 2017, $\mathrm{N}^{\circ}$ 1, p. 415, estaremos ante una expectativa legítima de privacidad cuando el sujeto pueda, razonablemente y sobre la base de antecedentes concretos y objetivos, considerar que su conducta o situación tienen el carácter de privado, lo que requerirá determinar si la expectativa de la persona afectada, de mantener algo como privado, se puede calificar como razonable y justificada en consideración a las circunstancias específicas del caso en cuestión.

${ }^{4}$ Suprema Corte (Estados Unidos), Katz v. United States, cit. (n. 3). La misma idea es recogida por la jurisprudencia española, como lo documentan Ros, cit. (n. 1), p. 36; MolinA, Teresa, "La entrada y registro practicada por la policía en el supuesto de flagrancia y la posesión de drogas en el domicilio particular", Anuario Jurídico y Económico Escurialense, 2004, Vol. XXXVII, p. 136 y Nogueras, Esther, "La investigación criminal sobre el domicilio: entrada y registro", Revista Internacional de 
Pero el legislador fue más lejos aún. El CPP delinea extremos y procedimientos para la entrada y registro de "edificios" y "lugares cerrados", sin requerir que éstos puedan catalogarse como el hogar del afectado, ni siquiera que en los mismos se observe un ámbito de privacidad protegido por el $\mathrm{N}^{\circ} 4^{\circ}$ del artículo 19 de la Constitución, opción acertada, pues de otra forma se autorizaría a agentes estatales para ingresar autónomamente y a su entero arbitrio a todo lugar cerrado que no reúna las características arriba mencionadas, con el inminente peligro de abuso y atropello del derecho de propiedad de terceros. ${ }^{5}$

En este contexto, en el que la protección de los derechos fundamentales amenazados o conculcados por la diligencia en examen debe ser el centro de atención, los principios de proporcionalidad, interpretación restrictiva y de especialidad, cumplen un rol primordial en la interpretación del estatuto que la regula, para su adecuado control preventivo y correctivo.

El principio de proporcionalidad examina la relación existente entre una medida de la autoridad, adoptada en el ámbito de sus facultades, gravosa para sus destinatarios, y la finalidad perseguida por esa medida, ${ }^{6}$ la que para adecuarse a este principio, debe satisfacer copulativamente tres requisitos: idoneidad, necesidad y proporcionalidad en sentido estricto, lo que en el ámbito que nos ocupa, puede leerse como adecuación de la investigación, insustituibilidad por otra medida menos lesiva, y gravedad del delito investigado. Este test de proporcionalidad se desenvuelve de manera sucesiva y escalonada a fin de evitar un sacrificio innecesario o excesivo que vulnere el contenido esencial del derecho fundamental ponderado. ${ }^{7}$

\footnotetext{
Estudios de Derecho Procesal y Arbitraje, 2016, № 1, p. 10.

${ }^{5}$ Horvitz y LóPEZ, cit. (n. 2), p. 514, excluyen como criterio para evaluar la vulneración de la garantía de inviolabilidad del hogar, el examen de si hubo o no realmente una lesión efectiva al derecho, conllevando la mera comprobación de un ingreso ilegítimo al domicilio, entre otros efectos, la exclusión probatoria o la prohibición de valoración de la evidencia que se hallare en dicho lugar. Sobre la protección de derechos fundamentales mediante la exclusión de información, v. Coloma, Rodrigo, "Panorama general de la prueba en el juicio oral chileno", en: Coloma, R., (Ed.), La Prueba en el Nuevo Proceso Penal Oral, LexisNexis, Santiago, 2003, $1^{\text {a }}$ ed., p. 15.

${ }^{6}$ Aldunate, Eduardo, Derechos fundamentales, LegalPublishing, Santiago, 2008, p. 264. También sobre este principio, v. HoRvitz y LÓPEZ, cit. (n. 2), pp. 353-354 y en lo referido a medidas cautelares DucE, Mauricio; Riego, Cristián, Proceso Penal, Editorial Jurídica, Santiago, 2009, p. 266; y Maturana, Cristián; Montero, Raúl, Derecho Procesal Penal, LegalPublishing, Santiago, $1^{\text {a }}$ ed., 2010, T. I, p. 441, y para la doctrina constitucional española, v. Ros, cit. (n. 1), p. 28.

${ }^{7}$ NúÑez, Raúl; Beltrán, Ramón; SAntander, Nicolás, "Los hallazgos casuales en las diligencias de incautación e intervención de las comunicaciones digitales en Chile. Algunos problemas", Política Criminal, 2019, v. 14, № 28, p. 159.
} 
Por su parte, la interpretación restrictiva de las disposiciones del CPP que autorizan la limitación de los derechos del imputado o del ejercicio de alguna de sus facultades, establecida en el inciso segundo del artículo 5 CPP en armonía con lo previsto en el $\mathrm{N}^{\circ} 26$ del artículo 19 de la Constitución, supone que dichas disposiciones no se apliquen a otros casos no regulados o bajo requisitos menos exigentes que los previstos expresamente por el legislador. ${ }^{8}$

$\mathrm{Y}$ en cuanto al principio de especialidad, éste viene referido a determinar el alcance de la resolución judicial habilitadora de la práctica de una determinada diligencia, de modo que sólo ciñéndose a ese ámbito se puede sostener su legalidad. Al respecto, el Tribunal Supremo español, en pronunciamiento de 2 de julio de 1994, ha explicado que la resolución judicial se otorga para una investigación específica y determinada, de modo que la autorización se refiere al concreto objeto de investigación y no a otro, para evitar las diligencias de prospección, por lo que no cabe decretar una diligencia limitativa de derechos para tratar de descubrir, en general, sin la adecuada precisión, otros actos delictivos. ${ }^{9}$

Estos tres principios, sin perjuicio de otros que puedan complementar y reforzarlos, conforman el instrumental exegético básico para alcanzar interpretaciones de la ley adjetiva respetuosas y deferentes con un diseño constitucional que reserva la dirección de la investigación al fiscal y no a las policías, que condiciona la privación, restricción o perturbación del ejercicio de los derechos que la Constitución asegura, por defecto, a aprobación judicial previa, y que tolera esas afectaciones en escenarios excepcionales y no como un desenvolvimiento y producto rutinario de la investigación.

Ahora bien, sin preterir la labor de los tribunales de instancia en el control preventivo y correctivo de la afectación de los derechos involucrados en la diligencia de entrada y registro, una labor esencial en lo último recae

\footnotetext{
${ }^{8}$ Sobre la interpretación restrictiva v. Chahú́n, Sabas, Manual del Nuevo Procedimiento Penal, LegalPublishing, Santiago, 2009, $6^{\text {a }}$ ed., p. 37; su aplicación, en general, respecto de las facultades autónomas de las policías, Horvitz, María I., "La Ley 20.931 sobre 'agenda corta"”, en: Defensoría Penal Pública (Eds.) Informes en Derecho. Doctrina Procesal Penal 2016-2018, Centro de Documentación DPP, Santiago, 2019, p. 65; y, específicamente en relación a esta diligencia, CerDA, cit. (n. 2), p. 265.

${ }^{9}$ Álvarez, Susana, "Los descubrimientos casuales en el marco de una investigación penal (Con especial referencia a las diligencias de entrada y registro en domicilio)", Revista Internacional de Estudios de Derecho Procesal y Arbitraje, 2011, No 2. También tratado por NúÑEz, Beltrán y SANTANDER, cit. (n. 7), p. 163.
} 
en la Corte Suprema, la que suele tener la última palabra en esta materia al conocer de recursos de nulidad fundados en la causal de la letra a) del artículo $373 \mathrm{CPP}$, esto es, la alegación de una infracción sustancial de derechos o garantías fundamentales. ${ }^{10}$ No obstante la acotada fuerza vinculante de sus pronunciamientos en virtud de lo señalado en el inciso $2^{\circ}$ del artículo 3 del Código Civil, no puede desconocerse la irradiación de las decisiones de nuestro Máximo Tribunal en la labor de los agentes de persecución así como en las resoluciones de los demás tribunales y, de ahí, la importancia de su estudio.

En esa labor correctiva, si bien la jurisprudencia que se examinará en este trabajo reconoce explícitamente la relevancia de los principios de proporcionalidad ${ }^{11} \mathrm{y}$ de interpretación restrictiva, ${ }^{12}$ así como implícitamente del principio de especialidad, ello aparece restringido a fallos aislados, ${ }^{13}$ básicamente con declaraciones y frases estereotipadas de limitada vigencia real, observándose en muchos otros la inaplicación de esos principios en la lectura de las normas legales pertinentes, las que, por ende se interpretan extensivamente en perjuicio del titular del derecho cautelado, o descuidando los extremos legales habilitantes. Todo ello, al final del día, trae aparejada una desmesurada e inválida ampliación de la autonomía de las policías para determinar, sin consulta o instrucción del fiscal ni autorización judicial, la ejecución de diligencias investigativas vulneratorias de derechos fundamentales. El estudio de las sentencias dictadas por la Corte Suprema en esta materia entre los años 2016 a 2020, en las que se tocan distintas temáticas de la diligencia de entrada y registro, como el concepto mismo de lugar cerrado, los requisitos habilitantes para su procedencia y condiciones para su ejecución, y los casos que requieren instrucción del fiscal o autorización judicial o del dueño o encargado, nos dará un amplio espectro para apreciar

\footnotetext{
${ }^{10}$ Acerca del control previo de afectación de derechos, GANDULFo, Eduardo, "Principios del derecho procesal penal en el nuevo sistema de procedimiento chileno", Revista de Derecho P. Universidad Católica de Valparaíso, 1999, Vol. XX, p. 437. Respecto a la causal del artículo 373 letra a) CPP, v. SANDAÑA, Lorena, "Recursos en el Código Procesal Penal", en: Oberg, H.; Cortez, G.; Manso, M.; Salas, Julio; Sandaña, L.; Valdés, R. (Coords.), Apuntes de Derecho Procesal Penal el Ministerio Público y el Proceso Penal Oral, LegalPublishing, Santiago, 2010, $8^{\text {a }}$ ed. p. 229, y Cortez, Gonzalo, El Recurso de Nulidad, LegalPublishing, Santiago, 2006, $2^{\mathrm{a}}$ ed., p. 145.

${ }^{11}$ Como en Corte Suprema, 15 de junio de 2020, Rol No 30709-20.

${ }^{12}$ Así en Corte Suprema, 7 de mayo de 2018, Rol No 5351-18.

${ }^{13}$ Por ejemplo, Corte Suprema, 31 de octubre de 2017, Rol No 39420-17; Corte Suprema, 12 de agosto de 2019, Rol N 15397-19; y Corte Suprema, 23 de diciembre de 2019, Rol № 26893-19.
} 
críticamente cómo ha evolucionado esta jurisprudencia y, principalmente, los defectos antes referidos, ello de la mano con nuestras propuestas de interpretación que permitan cerrar las puertas a transgresiones arbitrarias e innecesarias de derechos fundamentales, todo lo cual se compendia en las conclusiones finales.

\section{LUGAR CERRADO}

La diferencia entre lugar cerrado y de libre acceso público, expresiones que utilizan los artículos 205 y 204 CPP respectivamente, no radica en un aspecto material, esto es, si hay barreras físicas o no para entrar u observar lo que hay en el interior de un inmueble, sino si el acceso es libre o no, de manera más o menos indiscriminada, para terceros, lo cual, en caso afirmativo se opone al concepto de privacidad, como se daría en un restaurante no obstante que su administrador prefiera mantener las puertas juntas y abrirlas sólo ante el llamado de un comensal, pero no puede predicarse lo mismo a una casa habitación aun cuando su morador prefiera mantener sus puertas abiertas durante el día. De ese modo, en este último caso la morada puede catalogarse como un lugar cerrado, por lo que un ingreso de los policías sin anuencia, aprovechando que la puerta se halla accidentalmente abierta, puede considerarse una afectación del derecho fundamental a la privacidad, mientras en el primero se trata de un lugar de libre acceso al público, donde la entrada de los policías sin permiso generalmente no perturbará derecho alguno. ${ }^{14}$

Contrariamente, en fallo de 19 de febrero de 2020, Rol No 40.961-19, se tilda como "un lugar de libre acceso público" el patio de una mediagua emplazada en una quebrada que cuenta con un cierre incompleto. Desde luego, un cerco perimetral fragmentario o inconcluso no equivale a una vía franca para acceder a un predio $\mathrm{y}$, por consiguiente, para el registro de los policías sin necesidad de autorización del dueño o encargado o de la autoridad judicial, debiendo en cambio dirimirse si estos permisos pueden o no eludirse según si la actuación conmoverá o no un derecho fundamental, de otro modo, en desobediencia del artículo $19 \mathrm{~N}^{\circ} 26$ de la Constitución, se condicionaría la protección de la vida privada y la garantía

\footnotetext{
${ }^{14}$ Similares conclusiones en la jurisprudencia española son expuestas por NogUERAS, cit. (n. 4), p. 11.
} 
de la inviolabilidad del hogar sólo a aquellos domicilios que cuenten con un cerramiento perfecto, dejando a todos los demás, incluso a aquellos que no posean los recursos económicos para costearlo -con la consiguiente vulneración del derecho a la igualdad ante la ley-sujetos a la intromisión policial.

En otro orden de ideas, es posible concebir un lugar cerrado "dentro" de otro, supuesto que denominaremos de "círculos concéntricos", por concernir a espacios de privacidad diferenciados con distintos titulares, cada uno de los cuales entonces puede disponer de los propios pero no de los que corresponden exclusivamente al otro, como lo sería la habitación de un hijo mayor de edad o de un arrendatario, siempre que éstos hayan manifestado ostensiblemente una expectativa o interés de mantener un determinado espacio para un uso personal, con exclusión de la interferencia de los dueños o encargados del inmueble y que esa expectativa haya sido reconocida por éstos. No puede ignorarse que el arriendo o uso de habitaciones, recurrentemente, obedece a razones de precariedad económica que obstan para arrendar o adquirir toda una vivienda, por lo que no reconocer el derecho a privacidad en ese cuarto, por estrecho y precario que sea, comportaría una notoria violación del derecho a igualdad ante la ley, al condicionar el ejercicio y protección del derecho a la privacidad a cierto poder adquisitivo del morador.

En los susodichos supuestos la autorización para acceder a ese lugar deberá ser requerida a ese hijo o arrendatario y no al padre o arrendador que sea dueño o encargado del inmueble. ${ }^{15}$ Empero, los agentes policiales rehúyen de tal discriminación, probablemente por resultar más objetivo $\mathrm{y}$, por ende sencillo, identificar al dueño o encargado del inmueble como un todo.

Distinto colofón habrá si nos encontramos frente a dos o más moradores, cada uno los cuales reserva un sector del inmueble como privado, y esto es reconocido por el otro, mientras que comparten un área común, lo que podríamos graficar como "círculos secantes", o si se trata de quienes son comoradores de todo el lugar, porque como ha dicho el Tribunal Supremo español sobre estos últimos, "la convivencia supone una relación de confianza recíproca que implica la aceptación de que aquel con quien se

\footnotetext{
${ }^{15}$ Sigue esa línea NúÑEz, Raúl; CORREA, Claudio, "La prueba ilícita en las diligencias limitativas de derechos fundamentales en el proceso penal chileno. Algunos problemas", Ius et Praxis, 2017, $\mathrm{N}^{\circ} 1$, pp. 229 y 231, y el Tribunal Supremo español en sentencia de 6 de julio de 1995, citada por Ros, cit. (n. 1), p. 39.
} 
convive pueda llevar a cabo actuaciones respecto del domicilio común"16 $\mathrm{y}$, por lo tanto, cualquier cotitular de la vivienda podrá ejercer su derecho y permitir la entrada y registro del domicilio o, al menos, del área compartida.

En fallo que antecede al lapso comprendido por este estudio, de 11 de diciembre de 2014, Rol No 25003-14, la Corte invalida el resultado de la actuación de los policías que solicitan y obtienen de la dueña de un predio, la autorización para ingresar y registrar una cabaña en que vive el hijo de ésta, de manera independiente y que además se encontraba entonces cerrada, señalando que la norma que permite el ingreso y registro "ha de ser interpretada en relación a la garantía constitucional que tutela la privacidad del afectado y no la propiedad, situación entonces que demanda un mínimo de actividad por parte de las policías, en orden a establecer acertadamente la identidad del titular del derecho que va a ser lesionado".

Sin embargo, la jurisprudencia ulterior no se demora examinando estas distintas titularidades o cotitularidades, contentándose con constatar que el permiso proviene del dueño o encargado de la propiedad como un todo, como se observa en el pronunciamiento de 10 de febrero de 2020, Rol $\mathrm{N}^{\circ} 29.950-19$, en el que se valida el ingreso de los policías al dormitorio del imputado y la incautación de una escopeta hechiza que mantenía dentro de una mochila, en virtud de la autorización conferida por su madre. ${ }^{17}$ En casos como el que se comenta, el derecho fundamental a la privacidad conculcado no es el del dueño ni el del encargado del domicilio, sino el de un tercero que puede legítimamente ocupar ese espacio y modelar un entorno de privacidad reconocido por aquéllos, por lo que no resulta justificado que se solicite la renuncia a esa privacidad a quien no puede disponer de ella, debiendo los policías, de haber tomado conocimiento de tal circunstancia, requerir del verdaderamente afectado la autorización o, en su defecto, el permiso judicial.

${ }^{16}$ Referida por Nogueras, cit. (n. 4), pp. 19-20. Aunque como revelan los fallos expuestos por Ros, cit. (n. 1), p. 48, no estamos ante una cuestión pacífica en los tribunales ibéricos.

${ }^{17}$ Supuestos análogos se conocieron en Corte Suprema, 14 de noviembre de 2019, Rol N 27.546-19 y Corte Suprema, 11 de mayo de 2020, Rol N³3.150-20. 
III. PRESUNCIÓN REQUERIDA POR EL ARTÍCULO 205 CPP PARA LA REALIZACIÓN DE LA DILIGENCIA

El artículo $205 \mathrm{CPP}$, como manifestación del principio de proporcionalidad, condiciona el procedimiento de entrada y registro, dado lo intrusivo, perturbador y molesto del mismo para el morador u ocupante del inmueble, a la concurrencia de una "presunción" de que el imputado, o medios de comprobación del hecho que se investigare, se encontraren en su interior. La demanda de una presunción supone que debe presentarse un "hecho" del que pueda inferirse el concurso de las referidas circunstancias, esto es, presencia del imputado o medios de comprobación en el recinto ${ }^{18}$ $\mathrm{y}$, a su vez, que ese hecho sea "conocido", para lo cual debe converger un mínimo de antecedentes o un antecedente mínimo, que permitan así graduarlo, lo que debe ser corroborado por el órgano jurisdiccional en su control preventivo. ${ }^{19}$

Aseverar esta presunción tratándose de los hechos informados a los policías mediante una denuncia anónima, significa que la noticia viene ya revestida o acompañada de antecedentes ratificatorios de lo comunicado, que le dan una verosimilitud tal que permite analogarla al hecho conocido base de la presunción que señala el artículo 205. De no ser así, una delación de este tipo sólo debiera impulsar una indagación preliminar que dote de seriedad y credibilidad a lo informado. ${ }^{20}$

En el pronunciamiento de 27 de octubre de 2016, Rol № 65303-16,

\footnotetext{
${ }^{18}$ La doctrina del Tribunal Supremo español, resumida por NogUERAS, cit. (n. 4), p. 23, enseña que para decretar la diligencia de entrada y registro el juez debe basarla en sospechas fundadas, apoyadas en datos objetivos, elementos fácticos que determinen una base real de la que se pueda inferir que se ha cometido o se va a cometer un hecho delictivo. Sobre el "indicio" que demanda el artículo 545 de la Ley de Enjuiciamiento Criminal española, v. Tribunal Constitucional (España), 17 de diciembre de 1985, N 174, https://hj.tribunalconstitucional.es/es, consultada: 20 de abril de 2021. Sobre cómo debe proceder el fiscal o las policías en el ordenamiento nacional frente a esta presunción, CHAHUÁN, cit. (n. 8) p. 181. Por otra parte, en Corte Suprema, 5 de diciembre de 2017, Rol No 41356-17, se ha puntualizado que el artículo 205 CPP no requiere una "pluralidad" de indicios.

${ }^{19}$ Expone y analiza la jurisprudencia del Tribunal Constitucional español respecto a la exigencia de motivación del auto de entrada y registro, MoLina, Teresa, "La diligencia de entrada y registro practicada en la instrucción", Anuario Jurídico y Económico Escurialense, 2010, Vol. XLIII, pp. 134-135.

${ }^{20}$ En Tribunal Constitucional (España), 17 de enero de 2000, No 8, https://hj.tribunalconstitucional. es/es, consultada: 20 de abril de 2021, se declara que no será suficiente, por regla general, con la mención policial que se limita a justificar la petición de entrada y registro en alusión a fuentes o noticias confidenciales, la que habrá de ir acompañada de una previa investigación encaminada a constatar la verosimilitud de la imputación.
} 
la Corte sigue un derrotero diverso, considerando la denuncia anónima del cultivo no autorizado de cannabis sativa en un determinado lugar como bastante para impulsar las primeras diligencias de investigación, entre las que estimó pertinente el concurrir al inmueble mencionado en la denuncia y solicitar autorización para acceder al mismo, sin detenerse en los aspectos arriba examinados. En cambio, lo actuado por los policías en la decisión de 18 de julio de 2017, Rol No 24869-17, parece concordar con lo que se viene razonando, por cuanto, si bien se denuncia el mismo hecho punible y del mismo modo, esta vez los policías se acercan al lugar y, previamente, desde el exterior pueden ver las plantas referidas, lo que otorga sustento a lo informado secretamente y permite cimentar la presunción que la ley reclama, elementos que luego son notificados al fiscal, el que instruye solicitar el ingreso voluntario. ${ }^{21}$

\section{SOLICITUD DE AUTORIZACIÓN VOLUNTARIA PARA LA ENTRADA Y REGISTRO COMO ACTUACIÓN AUTÓNOMA}

Bien sabido es que la investigación es dirigida de forma exclusiva por el fiscal (artículo $83 \mathrm{CPR}$ y artículo $1^{\circ}$ de la Ley Orgánica Constitucional del Ministerio Público), debiendo las policías una vez recibida una denuncia informarle inmediatamente de ella (artículo $84 \mathrm{CPP}$ ) a fin de que éste entregue las instrucciones para llevar adelante la investigación, en su caso. En ese orden, las policías pueden realizar autónomamente sólo las pesquisas que expresamente autorice la ley, como aquellas enunciadas en el artículo 83 CPP y en otras disposiciones del mismo código o de leyes especiales, potestades que deben interpretarse restrictivamente, de modo que en cualquier otra hipótesis no prevista por la ley, prevalece la regla general por la cual se debe comunicar el hecho al fiscal de turno quien, de ser necesario, solicitara la autorización judicial correspondiente. ${ }^{22}$

\footnotetext{
${ }^{21}$ Revisa la satisfacción de este umbral también Corte Suprema, 3 de octubre de 2017, Rol № 36710 17.

${ }^{22}$ Examinan el carácter auxiliar de las policías en la investigación y problemáticas relacionadas, Gandulfo, cit. (n. 10), p. 424; Maturana y Montero, cit. (n. 6), p. 231; Carocca, Alex, Manual El

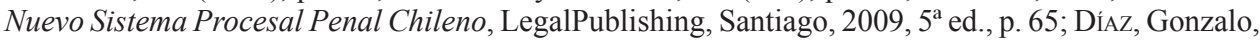
El control del narcotráfico, política criminal y proceso penal, Librotecnia, Santiago, 2011, $1^{\text {a }}$ ed., p. 85; Oberg, Héctor, "Derecho Procesal Penal Proceso Penal Oral”, en: Oberg, H.; Cortez, G.; Manso, M.; Salas, Julio; Sandaña, L.; Valdés, R. (Coords.), Apuntes de Derecho Procesal Penal el Ministerio
} 
El ruego de autorización al titular para la entrada y registro no aparece mencionado expresamente en el artículo $83 \mathrm{CPP}$ y, de considerarlo comprendido dentro de las primeras diligencias a que alude el inciso $4^{\circ}$ de la letra c) de dicho precepto, ello debe ir de la mano con su inclusión en instrucciones generales dictadas por el Ministerio Público conforme al artículo $87 \mathrm{CPP}$, en las que especifique, por mandato del artículo $83 \mathrm{CPP}$, los delitos respecto de los cuales procederá esta actuación.

El requerir que sea el fiscal quien instruya recabar la autorización del dueño o encargado, aunque sea a propuesta de la policía, vuelve factible que dicha autoridad pueda supervisar la presencia de la presunción antes comentada y, en definitiva, propender a que la actuación supere el test de proporcionalidad antes de importunar la privacidad e intimidad de un tercero. Por otro lado, de incluirse esta actividad como "primera diligencia" para determinados delitos en una instrucción general, en ésta deben entregarse criterios claros, precisos y restrictivos, sobre los supuestos en que proceda efectuar esa petición, como la gravedad del delito, el soporte de la denuncia y la necesidad de evitar la pérdida de evidencia, objetos o efectos del delito y, por otra parte, debe condicionarse a la imposibilidad de recabar la oportuna directriz del fiscal y a la urgencia de llevarla a cabo, de manera de priorizar y volver operativo su examen previo.

Pues bien, esta falta de instrucción del fiscal no ha sido una problemática que atraiga la atención de la Corte Suprema, la que nada más se enfoca en verificar la efectiva concesión de dicha autorización por el dueño o encargado, "purgando" con ello esa omisión. Con este criterio se descuida que, generalmente, los particulares, ante el requerimiento policial y la falta de consejo jurídico imparcial, permitirán el allanamiento, lo cual crea el riesgo que las policías soliciten indiscriminadamente y sin control previo, el acceso a domicilios respecto de los que tienen una infundada sospecha de que se encuentra el responsable o medios de comprobación de un delito, con el propósito de descartar o confirmar inmediatamente esa sospecha, obviando una indagación básica y controlada que justifique tal intromisión.

En la sentencia de 27 de octubre de 2016, Rol N 65303-16, la Corte

Público y el Proceso Penal Oral, LegalPublishing, Santiago, 2010, $8^{\text {a }}$ ed., p. 51; y en el ámbito comparado, Horvitz, cit. (n. 8), pp. 58-61. Un estudio sobre la reciente ampliación de las facultades de actuación autónoma de las policías, en OlIVER, cit. (n. 1), pp. 35-67. 
considera la solicitud de autorización al dueño o encargado dentro de las diligencias a que alude el inciso $4^{\circ}$ de la letra c) del artículo $83 \mathrm{CPP}$, bajo la única condición que sean las "primeras diligencias" y que además sean "pertinentes", sin atender si ha sido o no comprendida por alguna instrucción general. Luego, en decisión de 31 de enero de 2019, Rol N²9510-18, se resuelve que la venia del imputado sometido a control de identidad a quien se sorprende consumiendo y portando cannabis sativa, para la entrada y registro de su domicilio, hace innecesaria "autorización alguna" al respecto.

A diferencia de los pronunciamientos anteriores, y esta vez en la dirección correcta, con fecha 7 de mayo de 2018, Rol No 5351-18, se declara que el sorprender al imputado realizando una transacción de droga en la vía pública, si bien permite sospechar que puede almacenar más sustancia en su domicilio, no faculta a los policías para que, además de su aprehensión, le pidan autorización para ingresar a su hogar y lleven a cabo esa diligencia, sin previa comunicación e instrucción del fiscal. ${ }^{23}$ Explica la Corte que "una simple lectura de los literales del citado artículo 83 evidencia que el legislador no autoriza a las policías para determinar, autónomamente, la procedencia, pertinencia o utilidad de esta diligencia" y, además, aclara que "si bien el artículo 87 del Código Procesal Penal prescribe que el Ministerio Público 'podrá impartir instrucciones generales relativas a la realización de diligencias inmediatas para la investigación de determinados delitos', en el Oficio FN No 717-2017 que contiene instrucciones Generales sobre Primeras Diligencias (actualización a septiembre de 2017, incluso posterior a los hechos de autos), ninguna instrucción general relativa a la diligencia en estudio ingreso y registro de lugares cerrados - se entrega 'determinadamente' respecto del delito de tráfico de drogas (sino que se trata de manera general en relación al contenido de las actuaciones policiales autónomas, sin abordarlo después en las 'instrucciones generales por delito')". 24

\footnotetext{
${ }^{23} \mathrm{Al}$ contrario, sanciona la actuación policial por haber previamente obtenido la instrucción del fiscal, en Corte Suprema, 18 de julio de 2017, Rol N 24869-17 y Corte Suprema, 13 de febrero de 2019, Rol $\mathrm{N}^{\circ} 153-19$. Otro asunto diverso, no menos importante, son las dudas que puede generar la voluntariedad de la autorización, dada la privación de libertad que sufra el imputado al otorgar el permiso, como lo destaca NúÑEZ y CORREA, cit. (n. 15), pp. 224-225. La jurisprudencia del Tribunal Constitucional español, extractada por Morales, Emilia, "Diligencias de investigación en el proceso penal: La diligencia de entrada y registro. Tercer presupuesto: autorización judicial. Procedimiento para su práctica. Efectos de las entradas y registros domiciliarios inconstitucionales", Boletín del Ministerio de Justicia, 2007, No 2037, pp. 2122-2123 y Nogueras, cit. (n. 4), pp. 36-37, ha señalado que, si el titular del domicilio se encuentra detenido, se requerirá de la presencia de abogado para que su consentimiento resulte válido.

${ }^{24}$ Por cierto, no puede aceptarse que determinar qué se incluirá en las "primeras diligencias" sea
} 
V.LECTURA DE DERECHOS A QUIENSE SOLICITA LA AUTORIZACIÓN DE ENTRADA Y REGISTRO

$\mathrm{Si}$ a quien requiere la policía la autorización de entrada y registro puede endilgarse la calidad de imputado conforme al artículo $7 \mathrm{CPP}$, porque a la sazón ya se le atribuye responsabilidad en un hecho punible, esa persona podrá ejercer y reclamar el respeto de los derechos que en tal calidad le reconoce nuestro ordenamiento..$^{25}$

Esta afirmación, que así formulada pareciera no suscitar mayor dificultad, puede ir aparejada de atolladeros no menores, como determinar si, en el caso particular, el dueño o encargado a quien los policías solicitan el permiso, tiene ya la calidad de imputado y, segundo, si a éste deben leerse sus derechos previamente $\mathrm{y}$, de ser afirmativa la respuesta, qué derechos deben ser comunicados.

La Corte en los casos que le han sido planteados ha evitado un pronunciamiento concluyente sobre los últimos problemas, ya sea por desconocer la calidad de imputado al dueño o encargado, como ocurrió en el fallo de 12 de febrero de 2018, Rol N ${ }^{\circ} 45412-17$ o, sencillamente, por aprobar las actuaciones ejecutadas durante el ingreso y registro al contarse con una autorización voluntaria previa, como se observa en sentencias de 18 de marzo de 2019, Rol No 2875-19 y 12 de septiembre de 2019, Rol $\mathrm{N}^{\circ}$ 9187-19, sin ocuparse de que el consentimiento pudiera estar viciado precisamente por la omisión de esta información.

Lo perentorio de tal advertencia debe afincarse en el principio de no

$\overline{\text { definido por las mismas policías, pues ello implicaría un permiso ilimitado y anticipado para ejecutar }}$ cualquier tipo de pesquisa que no requiera orden judicial mientras no tome el control de la investigación el fiscal, en contradicción a la exclusividad de la dirección que éste ostenta, sin que tampoco aparezca ineludible forzar el texto en tal modo, desde que si se pretende no entorpecer o demorar la labor de los policías mientras se produzca esa comunicación, ello se puede lograr precisamente mediante la específica indicación de esas diligencias para determinados delitos en instrucciones generales.

${ }^{25}$ Sobre el momento de asunción del rótulo de imputado, NúñEz, Juan C., Tratado del Proceso Penal $y$ del Juicio Oral, Editorial Jurídica, Santiago, 2002, $1^{\text {a }}$ ed., T. I, p. 169. En Fiscalía Nacional, "Primeras Diligencias", 2017, documento disponible en línea http://www.fiscaliadechile.cl/Fiscalia/ instructivos/index.do, consultada: 14 de abril de 2020, p. 30, se instruye realizar esta lectura, pero sin precisar cuáles derechos deben ser informados, sólo indicando "especialmente del derecho a guardar silencio, explicando que está facultado a negarse a dar dicha autorización de entrada y registro". Gallegos, Antonio, "La inviolabilidad del domicilio y la diligencia de entrada y registro en domicilios particulares", Jueces para la democracia, 1987, $\mathrm{N}^{\circ} 1$, p. 33, expresa que si se dice que en el domicilio de una persona puede haber droga u objetos procedentes de un robo, ya está siendo denunciada como presunta partícipe de un delito. 
autoincriminación y en la inexistencia de un deber del imputado de aportar a la persecución seguida en su contra, pues al igual que una confesión, la entrega del objeto, efectos o instrumentos del delito, o de elementos que permitan su comprobación o determinar su participación, son actuaciones que contribuyen a la actividad estatal de persecución dirigida en su contra $\mathrm{y}$, por ende, de la misma forma que el imputado debe saber que puede abstenerse de declarar y aportar antecedentes que contribuyan a determinar su responsabilidad penal, igualmente debe conocer que puede negarse a autorizar el ingreso a un lugar cerrado del cual está a cargo o es dueño, para recoger objetos que afirmarán su participación en un ilícito penal, todo ello para que, si se allana a declarar o a que se acceda al lugar, se trate de una renuncia en verdad voluntaria, esto es, otorgada sabiendo que podía no haber cedido sin consecuencias adversas o, al menos, procurado previamente asesoría letrada. ${ }^{26}$

En definitiva, para que la autorización de entrada y registro a lugar cerrado entregada por el imputado se considere voluntaria, es menester que se le informe el hecho punible que se investiga, y sucintamente los antecedentes principales que respaldan la imputación y que justifican la solicitud y necesidad de ingresar al inmueble, su derecho a consultar a un abogado antes de responder al requerimiento y a denegar el permiso sin que ello conlleve consecuencias adversas, sin perjuicio de que el fiscal pueda solicitar al juzgado la autorización en ese caso, autoridad esta última que revisará si concurren los presupuestos legales para tal efecto. ${ }^{27}$ Huelga señalar que la entrega de esa información y su adecuado registro no excluye la posibilidad de que se ejerza coerción o presión indebida sobre el imputado para conseguir su permiso, pero constituye un paso básico en cautela de la voluntariedad de su autorización, pudiendo, por ende, discutirse igualmente su ausencia o su vicio en la instancia respectiva.

Una trama diversa es aquella en que el dueño o encargado a quien se solicita la autorización no tiene la calidad de imputado, sino que corresponde

\footnotetext{
${ }^{26}$ RodRíGUEZ, Manuel, "Diligencias investigativas por infracciones a la Ley N ${ }^{\circ} 20.000$ y debido proceso", en: SantibáÑez, M. (Dir.), Colección de análisis jurisprudencial, Rubicón, Santiago, 2020. Sobre esta materia, v. Medina, Gonzalo, "La primera declaración del imputado y el derecho a no declarar en perjuicio propio”, en: Coloma, R., (Ed.), La Prueba en el Nuevo Proceso Penal Oral, LexisNexis, Santiago, 2003, $1^{\text {a }}$ ed., p. 36.

${ }^{27}$ El voto de minoría de Corte Suprema, 12 de febrero de 2018, Rol № 45.412-17, estimó que deben comunicarse los derechos consignados en las letras a), b) y g) del artículo 93 CPP, que son los mismos cuya lectura impone el artículo 135 CPP.
} 
a una de las personas liberadas de declarar en su contra conforme al artículo 302 CPP, supuesto en que la Corte, en sentencia de 1 de agosto de 2019, Rol N $\mathrm{N}^{\circ}$ 17706-19, ha negado ese deber de información por estimar que no existe razón normativa que permita extrapolar esa advertencia ubicada entre las normas que gobiernan el juicio oral, a las primeras actuaciones del procedimiento. ${ }^{28} \mathrm{Sin}$ embargo, lo temprano de la actuación no es lo definitorio en esta disyuntiva, sino que el interés protegido mediante el artículo 302, esto es, la conservación de los vínculos familiares y afectivos, que reviste menor trascendencia que el derecho resguardado mediante la lectura de derechos al propio imputado -a la no autoincriminación- y que justifica extender los medios de protección de este derecho a otras actuaciones que pueden conculcarlo con igual intensidad. Creemos, por tanto, que este supuesto debe equipararse al del tercero sin relación con el imputado ni con la investigación a quien se solicita acceso a su domicilio por los policías, donde para afirmar la voluntariedad de su determinación bastará avisar del hecho punible que se investiga y las razones que hacen necesario el ingreso a ese lugar en particular. $^{29}$

\section{INGRESO Y REGISTRO A LUGAR CERRADO SIN AUTORIZACIÓN}

Las autorizaciones judiciales o del dueño o encargado del inmueble, admiten obviarse cuando ello sea vital para la promoción y aseguramiento del éxito de la investigación como para el resguardo de otros valores igualmente protegidos, tal como ocurre en las coyunturas detalladas en el artículo 206 CPP, cuya conveniencia en desmedro de los derechos a la privacidad y a la inviolabilidad del hogar debe dirimirse en función de un juicio de ponderación que actualice el principio de proporcionalidad, de la

\footnotetext{
${ }^{28}$ Sobre igual protesta, en Corte Suprema, 26 de marzo de 2020, Rol No 14.773-20, por la entrega por uno de aquellos enunciados en el artículo 302 CPP del teléfono celular del imputado a los policías, se señala que "dicho precepto alude a la facultad de no 'declarar' del cónyuge, conviviente y otros, y no de no 'entregar' objetos relevantes para la investigación".

${ }^{29}$ En Fiscalía, cit. (n. 25), p. 31, en cambio, se instruye a los policías que "cuando el encargado del lugar tenga respecto del imputado alguno de los vínculos de parentesco del artículo 302 Código Procesal Penal [...], el funcionario policial debe informarle que en dicha condición no tiene la obligación de declarar y que está facultado para negarse a dar dicha autorización" y, tratándose de un tercero, como se desprende del silencio del texto, no sería necesaria ninguna advertencia.
} 
mano de una aplicación restrictiva de las hipótesis que contempla. ${ }^{30}$

En decisión de 31 de mayo de 2016, Rol N²2088-16, la Corte ha explicado que el referido artículo 206 debe ser leído a la luz del artículo $130 \mathrm{CPP}$, que describe las realidades que la ley considera flagrantes, ${ }^{31}$ exégesis que obliga a una aclaración adicional, pues la remisión que aquella disposición haría a ésta, como parece entenderlo la Corte, se restringe solamente a la hipótesis contenida en su literal a), única que comulga con la contemporaneidad que llevan implícitas las llamadas o signos que indican que "se está cometiendo un delito", lo que a su vez, conduce a descartar el empleo de la definición de "tiempo inmediato" como un lapso de hasta de 12 horas, que establece el inciso final del citado artículo 130, pertinente exclusivamente para los restantes literales. ${ }^{32}$

Aún más. El principio de proporcionalidad, en un examen de necesidad sobre el contexto factual concreto, permite circunscribir las hipótesis enunciadas en el artículo 206 CPP, sólo a aquellas en que la demora que conllevaría solicitar la orden judicial por intermedio del fiscal, que incluso puede requerirse y otorgarse por cualquier medio idóneo como permite el inciso $3^{\circ}$ del artículo $9 \mathrm{CPP}$, pueda significar un peligro cierto para la vida o salud de aquel que pide auxilio, o para al éxito de la investigación por la destrucción de efectos o instrumentos del delito o por la fuga del autor, ${ }^{33}$ pauta a la que se ajustó el actuar policial en el caso conocido en pronunciamiento de 15 de julio de 2020, Rol No 69773-20, en el que los

${ }^{30}$ Concuerda, Molina, cit. (n. 4), p. 141 y así se reconoce en Corte Suprema, 25 de mayo de 2020, Rol N 30582-20.

${ }^{31}$ También Corte Suprema, 26 de marzo de 2018, Rol N² 2519-18; Corte Suprema, 6 de agosto de 2018, Rol N 14964-18; Corte Suprema, 24 de septiembre de 2018, Rol ํ 19099-18; y, Corte Suprema, 27 de enero de 2020, Rol No 33699-19. Horvitz y López, cit. (n. 2), p. 516, opinan que se trata de una hipótesis especial de flagrancia que se rige por el régimen jurídico general de la misma, que debe ser interpretada restrictivamente conforme lo dispuesto en el artículo 130 CPP.

${ }^{32}$ No obstante, en Corte Suprema, 27 de enero de 2020, Rol No 33.699-19, se alude al "contexto temporal que admite el artículo 130 del Código Procesal Penal”, sin precisar si la referencia es al concepto genérico de inmediatez o al plazo de 12 horas.

${ }^{33}$ Concordantemente, en Corte Suprema, 25 de mayo de 2020, Rol No 30.582-20, al analizar los supuestos del artículo 206 CPP, se señala que "la flagrancia encierra en sí las pruebas de su realización, es la percepción personal del hecho delictivo que se ve, se observa, de manera que en esta situación se precisa de una inmediata intervención policial a fin de que cesen el delito y sus efectos." De igual forma, Tribunal Constitucional (España), 18 de noviembre de 1993, N 341, https://hj.tribunalconstitucional. es/es, consultada: 20 de abril de 2021, explica que la autorización judicial que se exceptúa en los casos de flagrancia obedece a que la comisión del delito se percibe con evidencia y exige de manera inexcusable una inmediata intervención. 
funcionarios observan desde la vía pública que se mantenían plantas de marihuana en proceso de secado y, al no obtener respuesta de los ocupantes, resguardan el lugar e informan al fiscal, quien recaba la respectiva orden de entrada y registro del órgano jurisdiccional.

También afín a lo que se postula, en pronunciamiento de 13 de julio de 2016, Rol No 32863-16, la Corte sostiene que el artículo 206 CPP no autoriza el acceso si la policía deja transcurrir un lapso de 80 minutos desde la venta de droga presenciada en el inmueble por el requerimiento de personal de apoyo, ${ }^{34}$ criterio que después se abandona en decisión de 28 de febrero de 2017, Rol $N^{\circ}$ 145-17, al declarar que una demora de 45 minutos, no conlleva desvinculación de la flagrancia previa. ${ }^{35}$

Opuesto a una lectura restringida, en fallo de 28 de noviembre de 2019, Rol No 27082-19, se señala que el sorprender a una persona con droga cerca de su domicilio, cuando huía en dirección a éste después de ver a los policías, autoriza a los efectivos para acceder al inmueble, toda vez que dicho escenario "permitía inferir que, en ese lugar, existían más de las dosis que le fue hallada". Aunque lo que supone la Corte suena lógico, el estándar requerido por el citado artículo 206 de signos "evidentes" es holgadamente superior al que aquí se echa mano -inferencia-. Por lo demás, siendo aprehendido el imputado por un delito flagrante en la vía pública, no parecía impostergable irrumpir en su domicilio para evitar la destrucción de la droga que se creía dentro, prescindiendo del decreto judicial.

\section{SUJECIÓN ESTRICTA A LOS TÉRMINOS DE LA AUTORIZACIÓN DE INGRESO Y REGISTRO}

En apego al principio de especialidad, la autoridad judicial debe cuidar de indicar con precisión en su orden las menciones contenidas en las letras a) y d) del artículo $208 \mathrm{CPP}$, esto es, "El o los edificios o lugares que hubieren de ser registrados" y "El motivo del registro" que, a su vez, debe tener conexión con la presunción del artículo 205 que originó el

\footnotetext{
${ }^{34}$ Similar juicio en Corte Suprema, 27 de marzo de 2018, Rol N².794-18.

${ }^{35}$ Diversa situación es aquella en que el ingreso se fundamenta en una nueva (o segunda) flagrancia, de manera que el no entrar inmediatamente, no obstante darse una de las hipótesis que trata el artículo 206 CPP, no constituye un impedimento para hacerlo después si la misma se reitera, como se resolvió en Corte Suprema, 20 de marzo de 2017, Rol N 4.689-17.
} 
procedimiento. Asimismo, deben limitarse los espacios o sectores dentro del inmueble, de ser ello posible, sólo a aquellos en que se avizore factible cumplir la finalidad del registro. Pero incluso de callar estas directrices el decreto, el motivo de la orden igualmente debe orientar y circunscribir su ejecución por los policías. ${ }^{36}$

El registro o constancia de la orden judicial de entrada y registro permite fiscalizar la sujeción, tanto de la resolución judicial como de su ejecución por los policías, a las exigencias referidas, sin embargo, cuando este permiso es concedido por el dueño o encargado, desde luego estas consideraciones y restricciones no son tenidas en cuenta, otorgándose en general una autorización vaga y abierta para el ingreso, no limitada espacialmente -dado que sólo se responde a un requerimiento policial que por cierto tampoco viene revestido de esos límites - o, de serlo, no se deja registro que permita su control correctivo posterior. ${ }^{37}$

En relación con lo comentado en la sección V. at supra, sobre las condiciones para que pueda considerarse voluntaria la autorización, sea que quien la otorgue corresponda o no al imputado, pero con más urgencia en este último caso, debe informarse al dueño o encargado la razón por la que se le está pidiendo el permiso y, por consiguiente, se infiere necesariamente que si es concedido, lo es en función de ese motivo comunicado por los efectivos, lo que se alza como una limitación tácita a la actuación policial que debe ser honrada de la misma forma que si se hubiere formulado explícitamente o se consignare en una orden judicial. ${ }^{38}$

El fallo de 13 de agosto de 2014, Rol No 18011-14, aunque anterior al período abarcado por esta investigación, por su pertinencia resulta conveniente repasar. En el marco de una investigación por el robo de accesorios de vehículos, se obtiene autorización judicial y del encargado, para la entrada y registro de un inmueble, pero allanándose tanto el primero

${ }^{36}$ En Corte Suprema, 20 de noviembre de 2017, Rol No 40.698-17, se destaca la inconsistencia de revisar el cajón de un clóset, si la orden judicial de entrada y registro se emite para la detención de una persona.

${ }^{37}$ En Corte Suprema, 10 de febrero de 2020, Rol N²9.950-19, se expresa "Que la autorización otorgada por la propietaria del inmueble (...) se refería a toda la propiedad y no sólo al patio de ella, como lo sostiene el arbitrio, puesto que no fue controvertido que la madre del imputado autorizó la entrada y registro sin precisar que se refería a una dependencia determinada". Similar, Corte Suprema, 2 de julio de 2020, Rol No 24.703-20.

${ }^{38}$ Revisa diversas problemáticas de la autorización voluntaria, NÚÑEz, BELTRÁn y SANTANDER, cit. (n. 7), p. 179 y Ros, cit. (n. 1), p. 82. 
piso en que se ubica un taller mecánico, como el superior, donde se descubre bajo la cama matrimonial una escopeta artesanal, resolviendo la Corte que esta incautación se efectúa al margen de la ley, por cuanto, aun cuando la habitación del imputado se encuentra dentro del inmueble para el cual se visó la diligencia -sin distinción entre sus dependencias-, se entiende que dada la naturaleza de lo investigado, las autorizaciones se otorgaron sólo para el registro del taller mecánico. ${ }^{39}$

Asimismo, la decisión de 20 de noviembre de 2017, Rol N 40.6982017, dictamina que no puede utilizarse una orden de ingreso emitida para concretar la detención de un imputado que se presume se esconde en el inmueble de un tercero, para registrar éste con miras a encontrar evidencia de un delito investigado respecto de ese tercero, ${ }^{40}$ pronunciamiento que guarda coherencia con uno anterior al período cubierto por este estudio, de 6 de junio de 2007, Rol N 678-07, el que señala que la ejecución de una orden judicial de detención debe ajustarse al preciso y determinado objeto de la misma, pues de lo contrario se transformaría, de hecho, "en una verdadera orden amplia de investigar".

Lo que se viene explicando acepta entonces que una revisión exhaustiva y completa del inmueble, si no ha sido acortada por la autorización judicial o particular, se justifica si es funcional al motivo del permiso otorgado y a la naturaleza de los hechos investigados, como ocurre por ejemplo, tratándose del delito de tráfico ilícito de drogas, al ser una circunstancia conocida que la mantención de la sustancia en un domicilio por quien se dedica al comercio de la misma, no se realiza a simple vista, sino que se mantiene oculta y distribuida por diversos sectores y recovecos del inmueble, con el preciso objeto de impedir o dificultar su hallazgo por los organismos de persecución en el evento de un allanamiento sorpresivo, ${ }^{41}$ discernimiento al que se adhiere sentencia de 4 de octubre de 2016, Rol $N^{\circ} 47605-16 .{ }^{42}$

\footnotetext{
${ }^{39}$ Comenta y disiente, CORreA, Carlos, "El 'hallazgo casual' y sus consecuencias jurídicas”, Revista de Ciencias Penales, 2014, XLI, No 4, pp. 170-171.

${ }^{40}$ Similar, Corte Suprema, 1 de abril de 2015, Rol N².304-15.

${ }^{41}$ RodríGuez, cit. (n. 26), p. 284.

42 Sobre lo mismo, v. Corte Suprema, 10 de febrero de 2020, Rol N² 29.950-19 y Corte Suprema, 2 de julio de 2020, Rol No 24.703-20.
} 


\section{HALLAZGO CASUAL OCURRIDO DURANTE LA DILIGENCIA DE ENTRADA Y REGISTRO}

El hallazgo casual puede conceptualizarse como el encuentro fortuito o inesperado por los agentes de persecución de elementos probatorios no vinculados al delito que motiva la diligencia durante cuya ejecución son descubiertos, sea que se relacionen con una investigación distinta, o bien permitan advertir la existencia de un delito del que no se tenía conocimiento previo. $^{43}$

Analizaremos algunos de los puntos discutidos de esta actuación, al amparo de los pronunciamientos de nuestra Corte Suprema.

Si con ocasión del ingreso y registro autorizado a un inmueble se descubre en el interior objetos cuya posesión o tenencia puede constituir una situación de flagrancia (drogas ilícitas o armas de fuego prohibidas, por ejemplo), el lugar del hallazgo constituye un sitio del suceso, evento en el que los artículos 83 letra c) y $187 \mathrm{CPP}$, imponen a los policías recogerlos, identificarlos y conservarlos bajo sello sin necesidad de instrucción del fiscal u orden del tribunal. Esta idea parece inspirar lo resuelto en fallo de 14 de noviembre de 2019, Rol N²7.546-19 que, en lo que aquí nos interesa resaltar, establece que el interior del inmueble donde se amenaza de muerte a funcionarios de Carabineros, constituye el sitio del suceso de un delito flagrante. Amén de dicha incautación, procederá la detención del respectivo poseedor o tenedor, conforme a los artículos 83 letra b), 129 , inciso $2^{\circ}$, y 130 letra a) CPP, como se decidió en el pronunciamiento recién citado y también en sentencia de 8 de enero de 2018, Rol No 42.482-17.44

Corolario de lo anterior, el artículo 215 CPP cubriría únicamente situaciones no flagrantes ${ }^{45}$ en que existe, por tanto, una mera "sospecha" de

\footnotetext{
${ }^{43}$ Sobre la conceptualización de esta institución, su tratamiento en el derecho comparado y en el ámbito nacional, v. Marcazzolo, Ximena, "Hallazgos casuales en relación con los delitos de tráfico ilícito de drogas", Revista Jurídica del Ministerio Público, 2008, № 34, p. 150; NúÑEz, Beltrán y SANTANDER, cit. (n. 7), pp. 161-174; OlIVER, cit. (n. 1) p. 62-63; CORREA, cit. (n. 39), pp. 167-174; Horvitz, cit. (n. 8), pp. 78-79; y, en particular en el derecho español, Nogueras, cit. (n. 4), pp. 40-43 y Álvarez, cit. (n. 9) pp. 22-33.

${ }^{44}$ Semejantes, Corte Suprema, 4 de octubre de 2016, Rol No 47.605-16; Corte Suprema, 23 de enero de 2019, Rol No 31.248-18; y, Corte Suprema, 4 de abril de 2019, Rol ํ 4.264-19. Concuerdan en lo medular, MarCazzolo, cit. (n. 81), p. 151 y Correa, cit. (n. 78), p. 173. Como explica, Morales, cit. (n. 49), p. 2108, el consentimiento del titular, la flagrancia del delito y la autorización judicial son supuestos alternativos.

${ }^{45}$ Así lo aclaran Corte Suprema, 23 de abril de 2008, Rol No 7.005-07 y Corte Suprema, 23 de enero
} 
la existencia de un hecho punible distinto del que constituyere la materia del procedimiento en que la "orden judicial" se hubiere librado. ${ }^{46}$

Fuera de estos supuestos, otra incautación de especies encontradas accidentalmente en una diligencia de entrada y registro, y no relacionadas con el motivo de la misma, en general, solo es apropiada previo mandamiento judicial, de conformidad con lo establecido en el artículo 83, inciso tercero, de la Constitución y en los artículos $9^{\circ}$ y 217 CPP. Por ende, si el beneplácito fue dado por el mismo dueño o encargado, caso no comprendido por el artículo 215 CPP que únicamente se refiere a la actuación en virtud de decreto judicial, el hallazgo casual de un objeto que no configura una situación de flagrancia, pero que permite sospechar la existencia de un hecho punible distinto al que justificó la solicitud del permiso por parte de los policías, sólo puede ser incautado con la venia del poseedor o mandato del tribunal.

Antagónico a lo que aquí se postula, en pronunciamiento de 4 de octubre de 2016, Rol ํㅜ 47.605-16, el Máximo Tribunal reconoce que el artículo 215 CPP cubre exclusivamente el descubrimiento durante una diligencia ordenada judicialmente, sin embargo, agrega que de ser otorgada la autorización por el dueño o encargado, los objetos que se encuentren en virtud de un hallazgo casual -y sin limitar su afirmación a aquellos cuya posesión funde una situación de flagrancia-, pueden incautarse sin permiso del juez, toda vez que ese consentimiento -del dueño o encargado-, no menciona el "motivo" del registro como sí ocurre en la orden judicial, por lo que el allanamiento no se ve limitado por la naturaleza del ilícito pesquisado. ${ }^{47}$ $\mathrm{Y}$ en pronunciamientos posteriores, como el de 24 de septiembre de 2018, Rol N ${ }^{\circ} 19.052-18$, la Corte ha declarado que el artículo 215 CPP incluye también la entrada por autorización voluntaria del dueño o encargado, ${ }^{48}$ sin darse cuenta de la ampliación del radio de acción de esta norma que tal resolución conlleva, inadvertencia derivada, probablemente, de que en los procesos conocidos se trata de objetos cuya posesión crea un estado de

\footnotetext{
de 2019, Rol No 31.248-18.

${ }^{46}$ Ratifica que el artículo 215 CPP regula sólo la hipótesis de entrada y registro en virtud de orden judicial, Corte Suprema, 27 de octubre de 2016, Rol N 67.437-16 y Corte Suprema, 23 de enero de 2019, Rol N 31.248-18.

${ }^{47} \mathrm{La}$ Corte pasa por alto que la autorización voluntaria, en general, se entrega para el ingreso y registro del inmueble, pero no así para la incautación de lo eventualmente encontrado, por lo que ante el descubrimiento deberá procederse conforme a los artículos 187 y 217 CPP.

${ }^{48}$ También Corte Suprema, 1 de agosto de 2019, Rol N 17.706-19 y Corte Suprema, 2 de julio de 2020, Rol N²4.703-20.
} 
flagrancia que de todas formas habilitaba para su incautación.

\section{CONCLUSIONES}

La determinación de los casos y formas en que se afectan garantías fundamentales como el derecho a la privacidad y a la inviolabilidad del hogar, en la diligencia de entrada y registro a lugar cerrado, está sujeta y condicionada al imperio y respeto, entre otros, de los principios de proporcionalidad, interpretación estricta y especialidad, cuya vigencia debe actualizarse en cada actuación y decisión atingente, ya sea del órgano jurisdiccional o de los agentes de persecución.

Del estudio de los fallos dictados por nuestro Máximo Tribunal entre los años 2016 y 2020 se colige que dichos principios no priman o pesan adecuadamente en todas sus decisiones concernientes a la mentada diligencia, destacándose como aspectos principalmente obviados en dicha jurisprudencia, los siguientes:

1) Una exégesis estricta del concepto de lugar de libre acceso público, nos permite, por oposición, caracterizar adecuadamente el lugar cerrado más allá de barreras de ingreso o visión al interior, atendiendo en cambio a la ausencia de una entrada libre e indiscriminada para terceros, a quienes se excluye por ende del conocimiento de lo que se mantiene u ocurre adentro.

2) Como expresión del principio de proporcionalidad, para la procedencia de la diligencia de entrada y registro el artículo 205 CPP demanda un mínimo de antecedentes suficiente para erigir la base de una presunción de que el imputado, o medios de comprobación del hecho que se investigare, se encontraren en un determinado edificio o lugar cerrado, umbral que debe ser controlado preventivamente tanto por el fiscal como por el tribunal, al resolver las peticiones que le formulen las policías y el mismo fiscal, respectivamente, como correctivamente al revisar con posterioridad el órgano jurisdiccional la legalidad de la actuación en el caso de entradas toleradas por el dueño o encargado.

4) Tratándose del consentimiento del titular del derecho afectado, una interpretación estricta y ajustada al principio de proporcionalidad, debe limitar los supuestos en que los policías podrán requerirlo sin instrucción del fiscal, únicamente a aquellos que expresamente se regulen mediante instrucción general dictada por el Ministerio Público y en que, 
además, concursen razones cuya gravedad y urgencia justifique sortear esa comunicación.

5) Asimismo, si a quien se consulta es el propio imputado, para que se considere válido su permiso, es menester que se le instruya del hecho punible que se investiga, y sucintamente de los antecedentes principales que respaldan la imputación y que justifican la solicitud y necesidad de ingresar al inmueble, su derecho a consultar a un abogado antes de responder al requerimiento y a rechazarlo sin que ello conlleve consecuencias adversas, sin perjuicio de que el fiscal pueda solicitar al juzgado la autorización en ese caso, autoridad esta última que revisará si concurren los presupuestos legales para tal efecto. Si el requerido corresponde a una de las personas exentas de declarar en contra del imputado según el artículo $302 \mathrm{CPP}$, o a un tercero, para afirmar la espontaneidad de su asentimiento, nada más debe informársele el hecho punible que se investiga y explicársele la necesidad de entrar a su domicilio.

6) El reenvío que el artículo 206 CPP haría al artículo 130 CPP, abraza únicamente la hipótesis contenida en el primer literal de éste, pues el artículo 206 habla de llamadas o signos que indican que en el recinto "se está cometiendo un delito", por ende, "actualmente", excluyendo las de los demás literales y, consecuencialmente, repudiando la extensión máxima del "tiempo inmediato" a las 12 horas que establece el inciso final del artículo 130.

7) Dado que las policías deben reseñar al dueño o encargado la razón por la que se le pide el permiso de entrada y registro, si éste es concedido, lo será en función de ese motivo comunicado, lo que se alza como una limitación tácita que debe ser respetada al ejecutar la diligencia de la misma forma que si se hubiere formulado explícitamente por el particular o se consignare en una orden judicial.

8) Finalmente, si con ocasión del ingreso y registro autorizado a un inmueble se descubre en el interior cosas cuya posesión o tenencia equivale a un estado de flagrancia, el lugar del hallazgo será un sitio del suceso, evento en el que los artículos 83 letra c) y 187 CPP, imponen a los policías recogerlas, identificarlas y conservarlas bajo sello sin necesidad de instrucción del fiscal u orden del tribunal, amén de la detención que incumba contra el poseedor o tenedor, en su caso. En cambio, si brota únicamente la sospecha de un hecho punible distinto del que constituye la materia del procedimiento en que una orden judicial se hubiere despachado, 
conforme al artículo 215 CPP procederá sólo la incautación. Fuera de estos supuestos -flagrancia o sospecha de delito no relacionado al motivo de la orden judicial-, la incautación de piezas descubiertas accidentalmente en un procedimiento de entrada y registro únicamente será apropiada previa autorización del dueño o encargado u orden judicial.

El descuido de estos temas y problemáticas por la jurisprudencia de la Corte Suprema, posibilita que los agentes de persecución estatal sigan acudiendo a esta gravosa medida intrusiva como primer y prioritario recurso de investigación, de manera amplia, con un escaso control jurisdiccional y esencialmente formal, lo que trae como indeseado e inesperado efecto, abrir las puertas para una desmesurada e innecesaria transgresión de derechos fundamentales.

\section{BIBLIOGRAFÍA CITADA}

a) Doctrina

Aldunate, Eduardo, Derechos fundamentales, LegalPublishing, Santiago, 2008.

Álvarez, Susana, "Los descubrimientos casuales en el marco de una investigación penal (Con especial referencia a las diligencias de entrada y registro en domicilio)", Revista Internacional de Estudios de Derecho Procesal y Arbitraje, $2011, \mathrm{~N}^{\mathrm{o}} 2$.

Carocca, Alex, Manual El Nuevo Sistema Procesal Penal Chileno, LegalPublishing, Santiago, 2009, $5^{\text {a }}$ ed.

CERDA, Rodrigo, Manual del sistema de justicia penal, Librotecnia, Santiago, 2013, $2^{\mathrm{a}}$ ed., T. I.

Chaнuán, Sabas, Manual del Nuevo Procedimiento Penal, LegalPublishing, Santiago, 2009, $6^{\mathrm{a}}$ ed.

Coloma, Rodrigo, "Panorama general de la prueba en el juicio oral chileno", en: Coloma, R., (Ed.), La Prueba en el Nuevo Proceso Penal Oral, LexisNexis, Santiago, 2003, $1^{\text {a }}$ ed.

CORREA, Carlos, "El 'hallazgo casual' y sus consecuencias jurídicas", Revista de Ciencias Penales, 2014, XLI, No 4.

Cortez, Gonzalo, El Recurso de Nulidad, LegalPublishing, Santiago, 2006, $2^{\mathrm{a}}$ ed.

DíAz, Gonzalo, El control del narcotráfico, política criminal y proceso penal, Librotecnia, Santiago, 2011, $1^{\text {a }}$ ed. 

2009 .

Duce, Mauricio; Riego, Cristián, Proceso Penal, Editorial Jurídica, Santiago,

ESCOBAR, Javier, “¿Se vulnera el derecho a la privacidad si la policía utiliza, para efectos de una investigación criminal, fotografías del imputado obtenidas desde Facebook? Comentario a la sentencia rol No 3-2017 de la Corte Suprema", Estudios Constitucionales, 2017, No 1 .

Fiscalía Nacional, "Primeras Diligencias", 2017, p. 30, documento disponible en línea: http://www.fiscaliadechile.cl/Fiscalia/instructivos/index.do, consultada: 14 de abril de 2020.

Gallegos, Antonio, "La inviolabilidad del domicilio y la diligencia de entrada y registro en domicilios particulares", Jueces para la democracia, 1987, $\mathrm{N}^{\circ} 1$.

Gandulfo, Eduardo, "Principios del derecho procesal penal en el nuevo sistema de procedimiento chileno", Revista de Derecho P. Universidad Católica de Valparaíso, 1999, Vol. XX.

Hernández, Héctor, "La exclusión de la Prueba Ilícita en el Nuevo Proceso Penal Chileno", Colecciones de Investigaciones Jurídicas (U. Alberto Hurtado), 2004, No 2 .

HoRvitz, María I.; LóPEz, Julián, Derecho procesal penal chileno, Editorial Jurídica, Santiago, 2008, $1^{\mathrm{a}}$ ed., T. I.

Horvitz, María I., "La Ley 20.931 sobre 'agenda corta"”, en Defensoría Penal Pública (Eds.), Informes en Derecho. Doctrina Procesal Penal 2016-2018, Centro de Documentación DPP, Santiago, 2019.

Marcazzolo, Ximena, "Hallazgos casuales en relación con los delitos de tráfico ilícito de drogas", Revista Jurídica del Ministerio Público, 2008, 으 34.

Maturana, Cristián; Montero, Raúl, Derecho Procesal Penal, Legal Publishing Chile, Santiago, $1^{\mathrm{a}}$ ed., 2010, T. I.

MedinA, Gonzalo, "La primera declaración del imputado y el derecho a no declarar en perjuicio propio", en: Coloma, R., (Ed.), La Prueba en el Nuevo Proceso Penal Oral, LexisNexis, Santiago, 2003, $1^{\mathrm{a}}$ ed.

MolinA, Teresa, "La entrada y registro practicada por la policía en el supuesto de flagrancia y la posesión de drogas en el domicilio particular", Anuario Jurídico y Económico Escurialense, 2004, Vol. XXXVII.

MolinA, Teresa, "La diligencia de entrada y registro practicada en la instrucción”, Anuario Jurídico y Económico Escurialense, 2010, Vol. XLIII.

Morales, Emilia, "Diligencias de investigación en el proceso penal: La diligencia de entrada y registro. Tercer presupuesto: autorización judicial. Procedimiento para su práctica. Efectos de las entradas y registros domiciliarios inconstitucionales", Boletín del Ministerio de Justicia, 2007, No 2037.

Nogueras, Esther, "La investigación criminal sobre el domicilio: entrada y registro", Revista Internacional de Estudios de Derecho Procesal y Arbitraje, 
2016, $\mathrm{N}^{\mathrm{o}} 1$.

NúÑEz, Juan C., Tratado del Proceso Penal y del Juicio Oral, Editorial Jurídica, Santiago, 2002, $1^{\mathrm{a}}$ ed., T. I.

NúÑEz, Raúl; CORREA, Claudio, "La prueba ilícita en las diligencias limitativas de derechos fundamentales en el proceso penal chileno. Algunos problemas", Ius et Praxis, 2017, $\mathrm{N}^{\mathrm{o}} 1$.

NúÑEZ, Raúl; Beltrán, Ramón; SANTANDER, Nicolás, "Los hallazgos casuales en las diligencias de incautación e intervención de las comunicaciones digitales en Chile. Algunos problemas", Política Criminal, 2019, Vol. 14, № 28.

Oberg, Héctor, "Derecho Procesal Penal Proceso Penal Oral", en: OBerg, H.; Cortez, G.; Manso, M.; Salas, Julio; Sandaña, L.; Valdés, R. (Coords.), Apuntes de Derecho Procesal Penal el Ministerio Público y el Proceso Penal Oral, LegalPublishing, Santiago, 2010, $8^{\mathrm{a}}$ ed.

OLIVER, Guillermo, "Facultades autónomas de la policía en el sistema procesal penal chileno", Revista de Derecho P. Universidad Católica de Valparaíso, 2018, Vol. LI.

Rodríguez, Manuel, "Diligencias investigativas por infracciones a la Ley N 20.000 y debido proceso”, en: SANTiBáÑEz, M. (Dir.), Colección de análisis jurisprudencial, Rubicón, Santiago, 2020.

Ros, Emilia, La configuración jurídica de la orden de entrada y registro, Bubok, Madrid, 2017.

SAndAÑA, Lorena, "Recursos en el Código Procesal Penal", en: OBerg, H.; Cortez, G.; Manso, M.; Salas, Julio; Sandaña, L.; Valdés, R. (Coords.), Apuntes de Derecho Procesal Penal el Ministerio Público y el Proceso Penal Oral, LegalPublishing, Santiago, 2010, $8^{\mathrm{a}}$ ed.

\section{b) Normas citadas}

Ley $N^{\circ}$ 19.640, Ley Orgánica Constitucional del Ministerio Público, 1999

Ley $N^{\circ}$ 19.696, Establece Código Procesal Penal, 2000

Constitución Política de la República

\section{c) Jurisprudencia}

Corte Suprema, 6 de junio de 2007, Rol N 678-07

Corte Suprema, 23 de abril de 2008, Rol No 7.005-07

Corte Suprema, 13 de agosto de 2014, Rol No 18.011-14

Corte Suprema, 11 de diciembre de 2014, Rol No 25.003-14

Corte Suprema, 1 de abril de 2015, Rol N².304-15

Corte Suprema, 4 de enero de 2016, Rol No 89.660-16

Corte Suprema, 17 de mayo de 2016, Rol N 28.004-16

Corte Suprema, 31 de mayo de 2016, Rol N²2.088-16

Corte Suprema, 13 de julio de 2016, Rol N³2.863-16 
Corte Suprema, 4 de octubre de 2016, Rol N 47.605-16

Corte Suprema, 27 de octubre de 2016, Rol N 65.303-16

Corte Suprema, 27 de octubre de 2016, Rol N 67.437-16

Corte Suprema, 27 de febrero de 2017, Rol N 3-17

Corte Suprema, 28 de febrero de 2017, Rol N 145-17

Corte Suprema, 20 de marzo de 2017, Rol N 4.689-17

Corte Suprema, 18 de julio de 2017, Rol No 24.869-17

Corte Suprema, 24 de julio de 2017, Rol N²4.860-17

Corte Suprema, 3 de octubre de 2017, Rol N 36.710-17

Corte Suprema, 20 de noviembre de 2017, Rol 40.698-2017

Corte Suprema, 5 de diciembre de 2017, Rol N 41.356-17

Corte Suprema, 8 de enero de 2018, Rol N 42.482-17

Corte Suprema, 12 de febrero de 2018, Rol N 45.412-17

Corte Suprema, 26 de marzo de 2018, Rol N 2.519-18

Corte Suprema, 27 de marzo de 2018, Rol N 2.794-18

Corte Suprema, 7 de mayo de 2018, Rol No 5.351-18

Corte Suprema, 6 de agosto de 2018, Rol N 14.964-18

Corte Suprema, 24 de septiembre de 2018, Rol No 19.052-18

Corte Suprema, 24 de septiembre de 2018, Rol No 19.099-18

Corte Suprema, 23 de enero de 2019, Rol No 31.248-18

Corte Suprema, 29 de enero de 2019, Rol No 32.691-18

Corte Suprema, 31 de enero de 2019, Rol No 29.510-18

Corte Suprema, 13 de febrero de 2019, Rol N ${ }^{\circ} 153-19$

Corte Suprema, 18 de marzo de 2019, Rol No 2.875-19

Corte Suprema, 27 de marzo de 2019, Rol N 4.278-19

Corte Suprema, 4 de abril de 2019, Rol N 4.264-19

Corte Suprema, 1 de agosto de 2019, Rol N 17.706-19

Corte Suprema, 12 de agosto de 2019, Rol No 15.397-19

Corte Suprema, 12 de septiembre de 2019, Rol N 9.187-19

Corte Suprema, 14 de noviembre de 2019, Rol N²7.546-19

Corte Suprema, 28 de noviembre de 2019, Rol N²7.082-19

Corte Suprema, 23 de diciembre de 2019, Rol No 26.893-19

Corte Suprema, 27 de enero de 2020, Rol No 33.699-19

Corte Suprema, 10 de febrero de 2020, Rol N²9.950-19

Corte Suprema, 19 de febrero de 2020, Rol N 40.961-19

Corte Suprema, 11 de mayo de 2020, Rol No 33.150-20

Corte Suprema, 25 de mayo de 2020, Rol No 30.582-20

Corte Suprema, 15 de junio de 2020, Rol No 30.709-20

Corte Suprema, 2 de julio de 2020, Rol No 24.703-20

Corte Suprema, 15 de julio de 2020, Rol N 69.773-20

Corte Suprema, 8 de abril de 2021, Rol N ${ }^{\circ} 14.317-21$ 
Tribunal Constitucional (España), 17 de diciembre de 1985, $\mathrm{N}^{\circ}$ 174, https:// hj.tribunalconstitucional.es/es, consultada: 20 de abril de 2021

Tribunal Constitucional (España), 18 de noviembre de 1993, N 341, https:// hj.tribunalconstitucional.es/es, consultada: 20 de abril de 2021

Tribunal Constitucional (España), 17 de enero de 2000, $\mathrm{N}^{\circ}$ 8, https:// hj.tribunalconstitucional.es/es, consultada: 20 de abril de 2021

Suprema Corte (Estados Unidos), Katz v. United States, 389 U.S. 347 (1967), https://www.oyez.org/cases/1967/35, consultada: 20 de abril de 2021 